\title{
Synthesis of reduced graphene oxide nanosheets using nanofibers from methane and biogas thermal decomposition with various catalysts
}

\author{
Katarzyna Januszewicz ${ }^{1}$ (D) Ewa Klugmann-Radziemska ${ }^{1}$
}

Received: 18 September 2017 / Accepted: 20 February 2018 / Published online: 26 February 2018

(c) The Author(s) 2018. This article is an open access publication

\begin{abstract}
Reduced graphene oxide and graphene oxide ( $\mathrm{rGO}, \mathrm{GO})$ were synthesised from carbon nanofibers, which were formed in catalytic thermal decomposition of methane (CDM) and biogas with different catalysts used in the process. The aim of the work was valorization of CDM carbon nanofiber products. The samples were characterized using Raman spectra, a scanning electron microscope and a transmission electron microscope. As a result, we observe exfoliation and the sample surface to obtain the best samples of rGO and GO. These valuable products will be useful in improving the methane/biogas thermal decomposition process. The samples have been compared and a single layer of reduced graphene oxide can be seen on images. In addition, the influence of various catalysts (especially for $\mathrm{Fe} / \mathrm{Al}_{2} \mathrm{O}_{3}$ and $\mathrm{Ni} / \mathrm{Al}_{2} \mathrm{O}_{3}$ ) used in $\mathrm{CDM}$ on quality of samples was compared.
\end{abstract}

\section{Graphical Abstract}

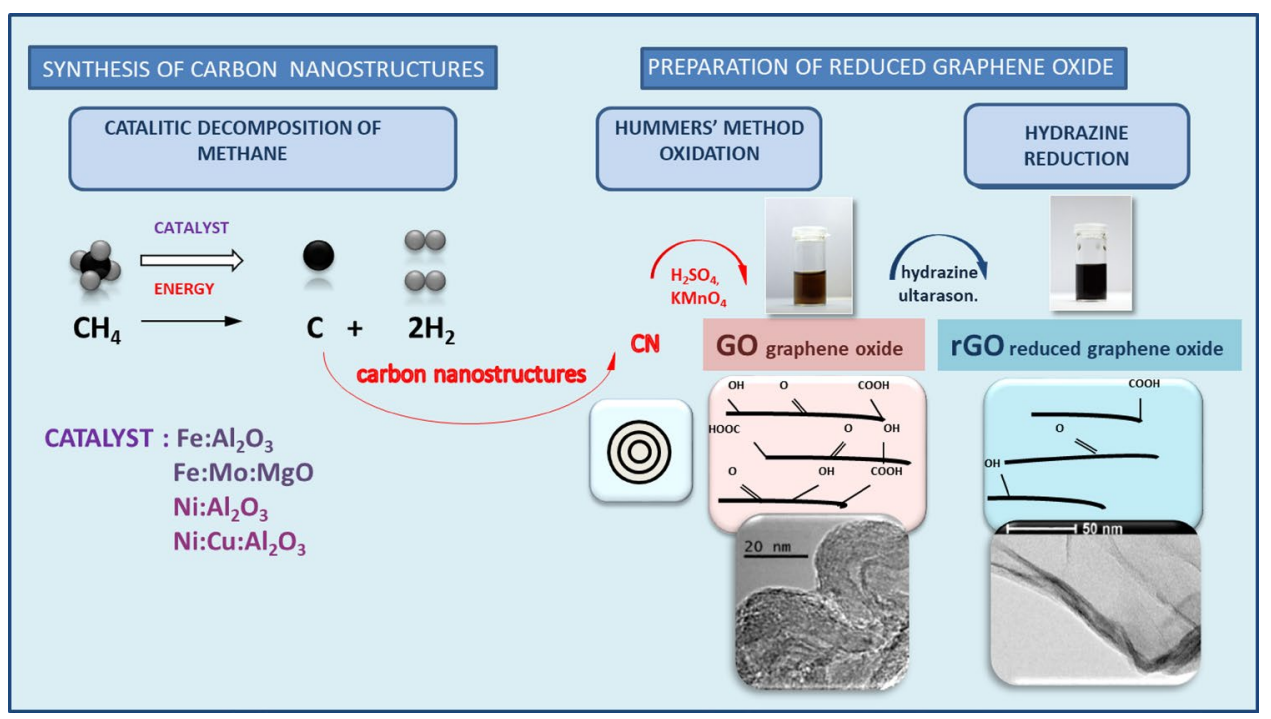

Keywords Reduced graphene oxide synthesis $\cdot$ Nanotubes $\cdot$ Catalytic thermal degradation of methane $\cdot$ Graphene oxide . Hummers' method

Katarzyna Januszewicz

katarzyna.januszewicz@pg.gda.pl

1 Gdansk University of Technology, Narutowicza 11/12,

80-233 Gdańsk, Poland 


\section{Introduction}

Carbon nanofibers were discovered during tests with fullerene materials using the arc technique (Iijima 1991; Martin 1994) and since then numerous applications of carbon nanofibers and nanotubes have become available, such as hydrogen storage (Benard and Chahine 2007), chemical sensors (Chambers et al. 1998), nanoscale electronic devices (Dillon et al. 1997), and catalytic support (Mirabile Gattia et al. 2009). In addition, various methods of generation of carbon nanofilaments are described, such as electrolysis of carbon dioxide, heat treatment of a polymer, low-temperature solid pyrolysis or in situ catalysis (Journet and Bernier 1998; Ren et al. 2015). The most used techniques for carbon nanotubes and nanofibers preparation include laser ablation, electric arc discharge, and chemical vapor deposition (Bayat et al. 2016; Fan et al. 2015; Journet and Bernier 1998). Another popular method is the thermal decomposition process, which is used in the Institute of Carbon in Zaragoza. This method has the best efficiency of product formation and allows control of the structure and morphology of carbon nanotubes through modification of the catalyst composition and reaction parameters (Rostrup-Nielsen et al. 1998; Zou et al. 2006). It is critical in the process to control the high temperature in the furnace and the selection of catalyst. Catalytic thermal decomposition of methane (CDM), which is a technique for hydrogen generation and additionally filamentous carbon formation, was used in this investigation (Ayabe et al. 2003; Ermakova et al. 2001; Fan et al. 2015; Moliner et al. 2006; Oberlin et al. 1976). Moreover, this method is an alternative way of hydrogen production from natural gas, biogas, syngas and other hydrocarbons (Bjorn Gaudernack 1998; Benard and Chahine 2007; Goodman et al. 2006; Rostrup-Nielsen et al. 1998). Biogas mainly composed of $\mathrm{CH}_{4}$ and $\mathrm{CO}_{2}$ generally is used for the generation of heat, electricity, combined heat and power, different alternatives for utilization, in the production of syngas $\left(\mathrm{H}_{2}\right.$ and $\left.\mathrm{CO}\right)$ or hydrogen (Pinilla et al. 2017). Different parameters used in the catalyst thermal decomposition process, such as temperature, various catalysts, and gasses, form carbon nanofilaments such as single-wall nanotubes, multi-wall nanotubes, a platelet, fishbone solid, fishbone hollow core, ribbon, and stacked cup (Martin-Gullon et al. 2006). Conventional catalysts used in the methane decomposition process are iron, nickel, copper supported on different metal oxides such as alumina, silica, magnesia, titania, and others (Bayat et al. 2016; Horváth et al. 2011). Various carbon forms such as graphite layers with metal particles, filaments of amorphous carbon, multiwalled nanotubes, amorphous carbon layers on catalysts can be generated in the thermal catalytic decomposition process (Journet and Bernier 1998). Multiwalled carbon nanofibers are composed of graphene sheets oriented at an angle to the nanotube axis, in bamboo structure graphene sheets are curled inwards (Bayat et al. 2016). In this work, those nanofilaments were used in the graphene synthesis process. The aim of the work was to prepare reduced graphene oxide (rGO) and graphene oxide (GO) samples from different nanofibers, which were obtained in catalytic thermal degradation of methane or biogas. The efficiency of this synthesis was assessed by comparison of the surface of rGO and $\mathrm{GO}$ which was obtained from nanofibers. rGO materials were synthesised by chemically reducing exfoliated GO. Nanofiber samples were prepared using catalytic methane or biogas decomposition with different catalysts and temperatures.

The main reasons for graphene synthesis are their physical, mechanical and optical properties, such as high electrical and thermal conductivity, strength, elasticity, mechanical hardness, excellent electron transport, nano-dimensions which allow reducing the size of devices, and others (Kim et al. 2010). It is of interest for industrial application and practical uses in many fields, such as electronics, transistors, solar cells, supercapacitors, hydrogen storage, sensors, and memory devices. The quality of graphene and reduced graphene oxide samples depends on the synthesis method, such as chemical vapor deposition, arc discharge, reduction of $\mathrm{CO}$, unzipping carbon nanotubes, chemical conversion, and self-assembly of surfactants (Kim et al. 2010). The process usually starts from graphite and graphene oxide, which is formed in the aqueous or organic medium by exfoliation methods. Exfoliation dispersion is reduced using different methods. In this investigation, graphene oxide was prepared using the Hummers' method (Hummers and Offeman 1958), then samples were reduced using hydrazine hydrate and exfoliated by ultrasonication. GO has application in many fields, an example is preparing composite materials with NBR (nitrile-butadiene rubber) modifying exfoliated GO (Zhang and Cho 2017). Graphene oxide reduction using hydrazine was carried out without surfactants, what is more, this method could be easily realized in large-scale production of the aqueous graphene dispersion (Kim et al. 2005). This is a promising method for industrial graphene production, in this study, we used products of thermal degradation of methane or biogas. These materials were characterized by a scanning electron microscope-SEM, a transmission electron microscope-TEM and Raman spectroscopy. Moreover, catalytic thermal degradation of methane or biogas will be more profitable. 


\section{Experimental}

\section{Materials}

\section{Carbon nanofiber synthesis}

In this work, carbon materials were obtained in two different processes: catalytic degradation of methane or biogas. Catalysts traditionally used in CDM consist of transition metals belonging to group VIII supported on various metal oxides (Abbas and Wan Daud 2010). CDM was carried out at $800{ }^{\circ} \mathrm{C}$ with three different catalysts, such as $\mathrm{Fe}_{2} \mathrm{O}_{3} /$ $\mathrm{Al}_{2} \mathrm{O}_{3}$ (molar ratio 1:1); $\mathrm{Fe}_{2} \mathrm{O}_{3} / \mathrm{Mo} / \mathrm{MgO}$ and $\mathrm{NiCuAl}_{2} \mathrm{O}_{3}$. The preparation of catalysts was described elsewhere (Lázaro et al. 2015), briefly-catalysts were prepared by fusing the nitric salt of nickel (or copper, iron) with the nitric salt of aluminum, then these were decomposed at $350{ }^{\circ} \mathrm{C}$ and calcination performed at $450{ }^{\circ} \mathrm{C}$. Different temperatures of reduction were used to evaluate the purity of hydrogen production and influence of the pre-reduction treatment of catalyst. In this investigation, the influence of temperature treatment on graphene layers was tested: carbon nanotubes were subjected a various temperatures in oven: 800,1500 and $2800{ }^{\circ} \mathrm{C}$ with $\mathrm{Fe}_{2} \mathrm{O}_{3} / \mathrm{Al}_{2} \mathrm{O}_{3}$ (molar ratio 1:1) as catalysts.

Nanofibers were also prepared during catalytic biogas degradation. Biogas is mainly composed of methane and carbon dioxide and in experiments mixtures of gasses containing $\mathrm{CH}_{4}$ and $\mathrm{CO}_{2}$ (50\%:50\%) were used, there was no $\mathrm{H}_{2} \mathrm{~S}$ which could cause corrosion problems. The process was carried out in a rotary-bed reactor heated by an electric furnace at $700{ }^{\circ} \mathrm{C}$ for the reaction with the catalyst Ni/ $\mathrm{Al}_{2} \mathrm{O}_{3}$ (Ni:Al molar ratio 2:1) (Pinilla et al. 2011).
Additional information on experimental apparatus can be found in Ref. (Sebastián et al. 2009).

The aim of the work was to synthesize graphene-like structures in a two-step process from different carbonaceous nanomaterials. The samples of nanofilament carbon were from catalytic methane or biogas decomposition with three catalysts and from CDM at various temperatures of the process.

\section{Syntheses of GO and rGO}

The synthesis of rGO takes place in two steps: graphene oxide preparation and reduction (Fig. 1). Carbon nanofibers and nanotubes from catalytic methane or biogas degradation were used as substrates for the synthesis of graphene oxide. The synthesis was carried out using the Hummers' method (Hummers and Offeman 1958). Carbon nanotubes or nanofibers $(1 \mathrm{~g})$ and $\mathrm{NaNO}_{3}(0.5 \mathrm{~g})$ were mixed, then sulfuric acid $(50 \mathrm{~mL} ; 98 \%)$ was added. The solution was mixed in a beaker with an ice bath, then $\mathrm{KMnO}_{4}(3 \mathrm{~g})$ was added slowly, the temperature of the solution must be below $20^{\circ} \mathrm{C}$. After $2 \mathrm{~h}$ of stirring, the ice bath was removed and the temperature of the mixture was brought to $35^{\circ} \mathrm{C}$, and then was stirred for $18 \mathrm{~h}$ and the color of the solution became brown. Distilled water $(75 \mathrm{~mL})$ was slowly added and the temperature of the solution needed to be below $50{ }^{\circ} \mathrm{C}$. Then water $\left(120 \mathrm{~mL}, 50{ }^{\circ} \mathrm{C}\right)$ with $\mathrm{H}_{2} \mathrm{O}_{2}(2.5 \mathrm{~mL} ; 30 \mathrm{wt} \%)$ was added and stirring continued for $2 \mathrm{~h}$. The suspension was filtrated, washed with $250 \mathrm{~mL}$ of $\mathrm{HCl}(10 \%)$, water and ethanol, and dried all night in a vacuum oven at $70{ }^{\circ} \mathrm{C}$.

The second step starts with $100 \mathrm{~mL}$ of distilled water added to $250 \mathrm{mg}$ of graphene oxide (GO) and the solution was stirred with a magnetic bar until the solution became homogeneous and with a black color. Hydrazine hydrate $(250 \mu \mathrm{L})$ was used for reduction and the solution was

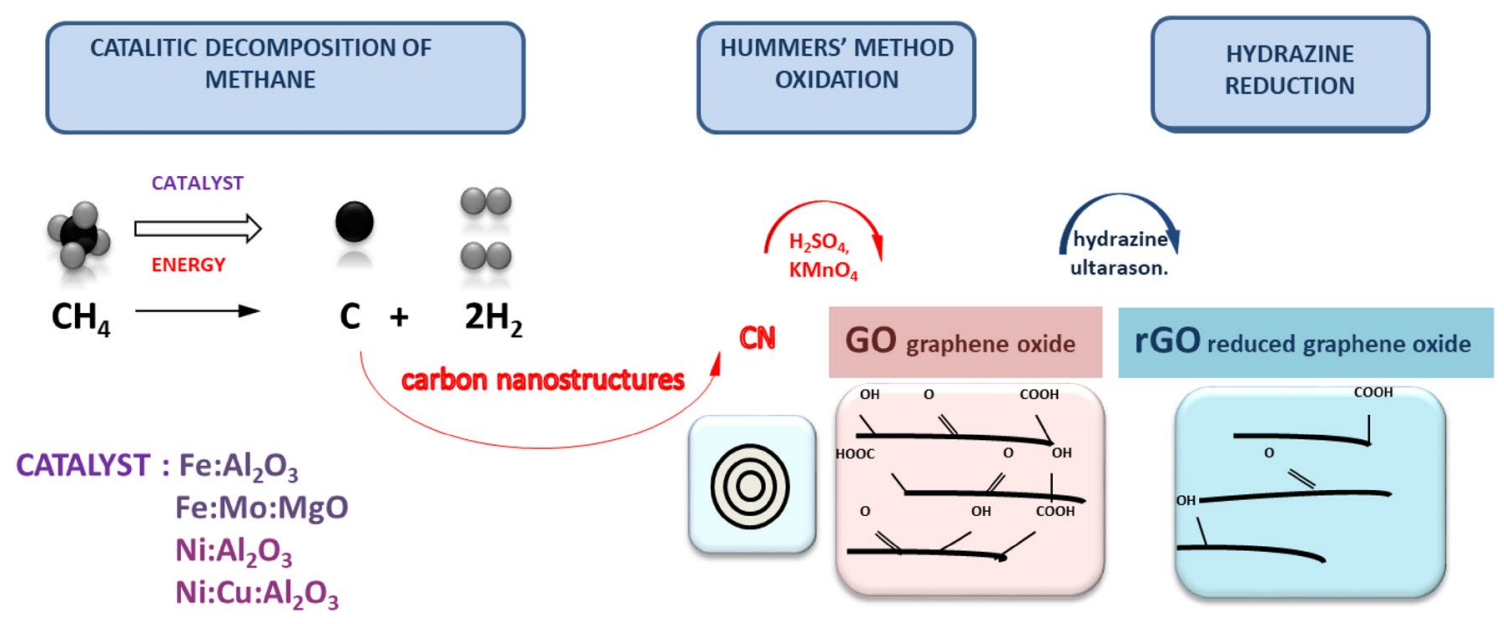

Fig. 1 Schematic of preparation of reduced graphene oxide 
sonicated to exfoliation for $30 \mathrm{~min}$. Then, the sample was dried at $100{ }^{\circ} \mathrm{C}$ all night.

\section{Results and discussion}

Raman spectroscopy measurements were conducted to investigate the structure of the synthesized GO and rGO samples. Raman spectroscopy is one of the most versatile tools to study the structure of carbonaceous materials. The structural changes of the carbon lattice that arose during chemical processing of graphene oxide to reduced graphene oxide are reflected in the presented Raman spectra (Fig. 2). The Raman spectrometer is a nondestructive device useful to characterize the degree of structural order, crystallization and defects in carbon material (Cao et al. 2015; Cuesta et al. 1994). There are several methods for deconvolution of Raman spectra, including 3-, 4- or 5-peak models of the first-order spectra. In this work, we used the 4-peak model to fit first-order spectra due to achieving the best fitting accuracy for this model. The curve fitting results obtained in the present study utilize a Lorentziantype peak for all the spectra. The results of the fitting procedure of the graphene oxide and reduced graphene oxide spectra are presented in Table 1. The first-order spectra of both samples include: the D-band at $\sim 1343 \pm 4 \mathrm{~cm}^{-1}$, the G-band at $\sim 1576 \pm 5 \mathrm{~cm}^{-1}$, the $\mathrm{D}^{\prime}$-band at $1607 \pm 4 \mathrm{~cm}^{-1}$ and the $\mathrm{D}^{\prime \prime}$-band at $1502 \pm 11 \mathrm{~cm}^{-1}$. As known from the literature, in the Raman spectra of disordered carbonaceous materials, a small I-peak can be observed at about $900-1200 \mathrm{~cm}^{-1}$, that can be ascribed to the disordered graphitic lattice (Dettlaff et al. 2017). The I-band is very often treated as a shoulder of the D-band. Due to its low intensity, we did not take the I-band into account in Raman spectra analyses. The D-band arises as a consequence of a lattice disturbance like the edge of the graphene layer or

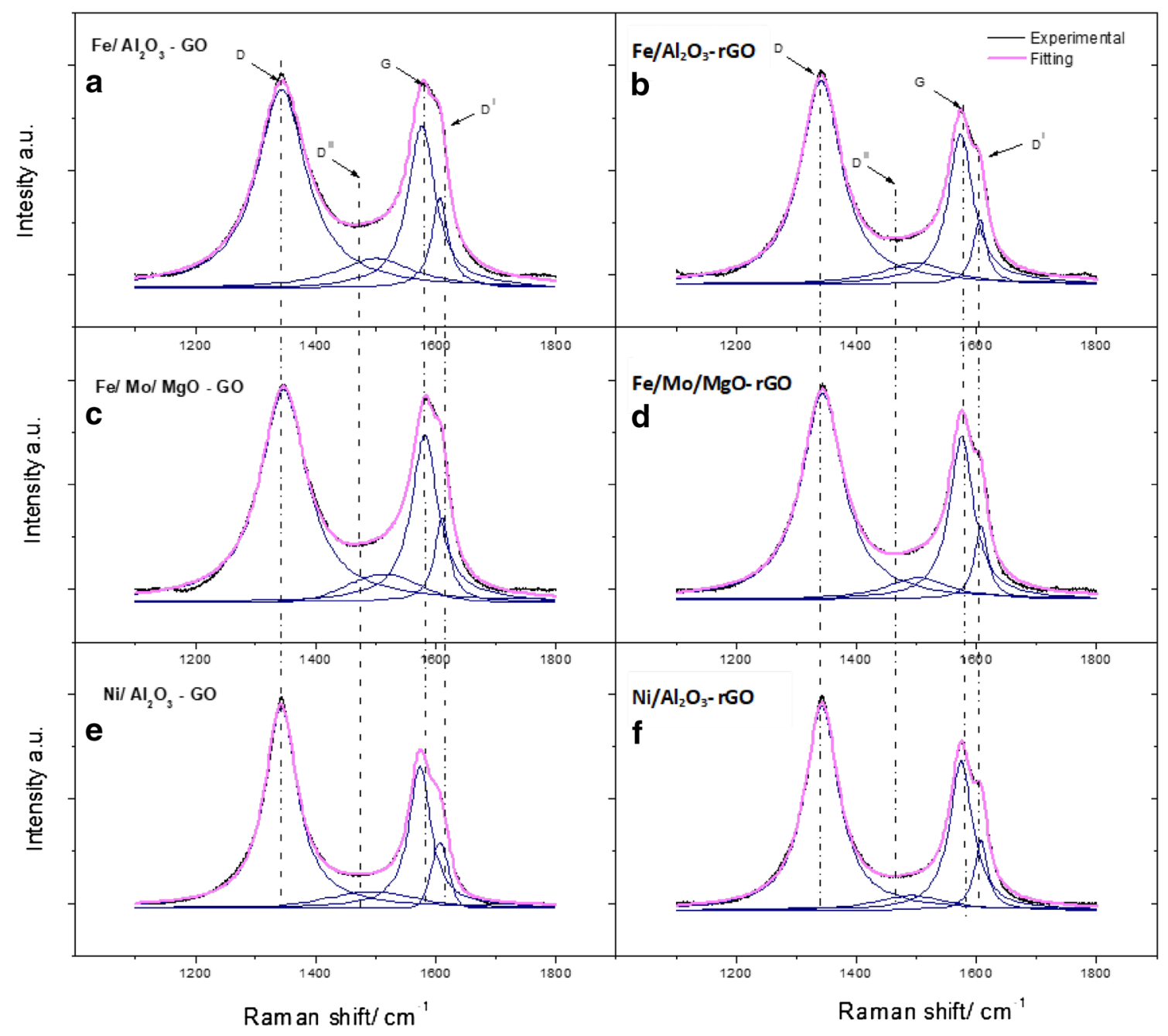

Fig. 2 Curve fit with first-order band combination for $\mathrm{GO}$ and $\mathrm{rGO}$. a GO with $\mathrm{Fe} / \mathrm{Al}_{2} \mathrm{O}_{3}$ catalyst, b rGO- $\mathrm{Fe} / \mathrm{Al}{ }_{2} \mathrm{O}_{3}$, c GO- Fe/Mo/MgO, d rGO$\mathrm{Fe} / \mathrm{Mo} / \mathrm{MgO}$, e GO- $\mathrm{Ni} / \mathrm{Al}_{2} \mathrm{O}_{3}$, f $\mathrm{rGO}-\mathrm{Ni} / \mathrm{Al}_{2} \mathrm{O}_{3}$ 


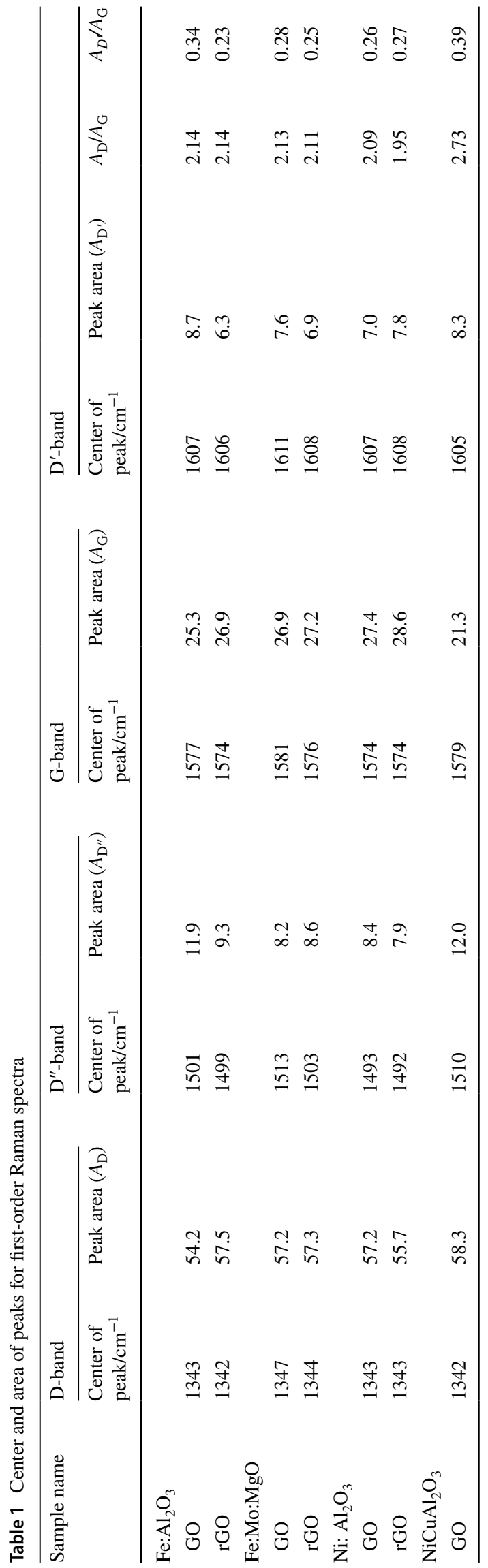

heteroatoms present in the carbon lattice (Sadezky et al. 2005). In general, Raman spectra of pure and high-quality graphene do not show the D-band. However, in the case of reduced graphene oxide, the D-band always appears in the spectrum, indicating disorder of the carbonaceous layers. In the case of the Raman spectra of the investigated GO and rGO samples, a quite broad D-band is observed. One should bear in mind that the samples used in this experimental work might be inhomogeneous and the presence of amorphous carbon or graphite could give such a shape of the D-band and additional presence of $\mathrm{D}^{\prime \prime}$-band. These $\mathrm{D}$ and $\mathrm{D}^{\prime \prime}$ bands are attributed to a disordered symmetry of $\mathrm{sp}^{2}$ carbon, which might be caused by many effects: amorphous carbon ( $\mathrm{D}^{\prime \prime}$ peak presence), incorporated heteroatoms (in the case of the investigated samples, the heteroatoms such as $\mathrm{Ni}, \mathrm{Fe}$, and Mo might be present in the carbon lattice as a catalyst residue from the CDM process), functional groups, defects of the tube, etc. (Cuesta et al. 1994; Ferrari et al. 2006; Ferrari and Robertson 2000; Sadezky et al. 2005). Changes in shape and intensity of the $\mathrm{G}$ peak of reduced graphene oxide compared to graphene oxide samples are shown in Fig. 2. Earlier studies have reported that an increasing degree of graphitization is involved with the decreasing G- and D-band (Sadezky et al. 2005). According to the literature reports, the number of defects in the carbon material may be quantified by the peak area ratio of D- and G-bands and also $\mathrm{D}^{\prime}$ and $\mathrm{G}$. As shown in Table 1, the reduction of GO caused, in most of the samples, a slight decrease of the $A_{\mathrm{D}} / A_{\mathrm{G}}$ and $A_{\mathrm{D}^{\prime}} / A_{\mathrm{G}}$ ratio. In addition, the height and area of the $\mathrm{D}^{\prime}$-bands are smaller in the case of GO samples than in the case of rGO. Samples where $\mathrm{Ni} / \mathrm{Al}_{2} \mathrm{O}_{3}$ was the catalyst were an exception. When analysing the $\mathrm{G}$ bands of Raman spectra (peak at $\sim 1576 \mathrm{~cm}^{-1}$ ) one may observe that the peak area decreases with progression of the reduction process.

The second-order Raman spectra of GO and rGO samples are presented in Fig. 3. They consist of two broad peaks, namely 2D-band that appear at around $2700 \mathrm{~cm}^{-1}$ and the D + G- band at approx. $2900 \mathrm{~cm}^{-1}$. The 2D-band corresponds to the overtones of the first-order D-band, whereas the $D+G$ appears due to the combination of the $\mathrm{G}$ and $\mathrm{D}$ mode characteristics for disturbed graphitic structures (Cuesta et al. 1994; Sadezky et al. 2005). Quantitative analysis of these spectra was not done because the evaluation would be ambiguous due to a lot of interferences. However, the second-order spectra of reduced graphene oxide samples ( $\mathrm{rGO}-\mathrm{Fe} / \mathrm{Al}_{2} \mathrm{O}_{3}$, and $\mathrm{rGO}-\mathrm{Fe} / \mathrm{Mo} /$ $\mathrm{MgO}$ ) (Fig. 3b, d) exhibit a higher intensity of $\mathrm{D}+\mathrm{G}$ band.

The presented results of Raman measurements indicate that the reduction process of graphene oxide samples is not complete and the rGO samples present disordered structure. 


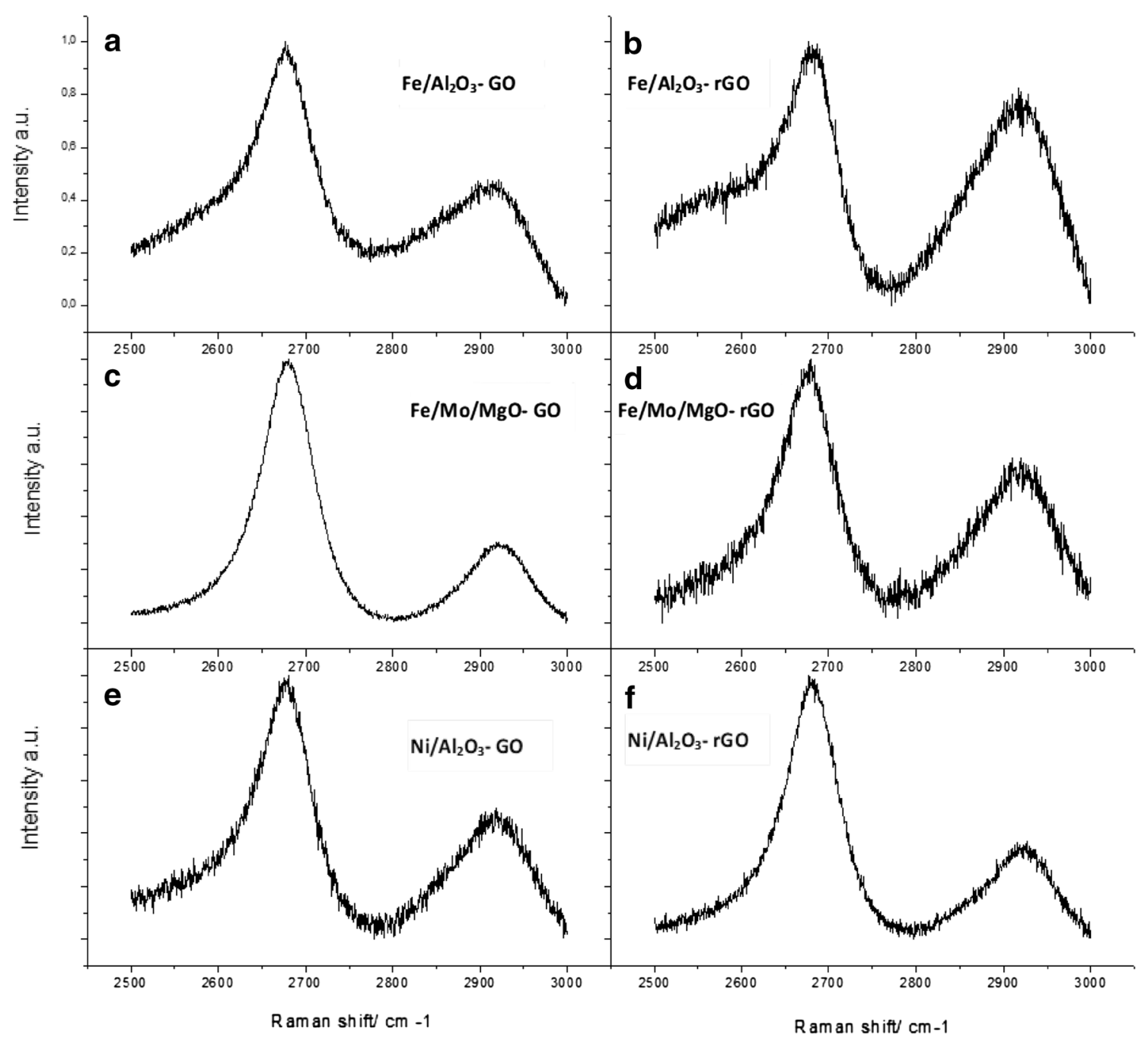

Fig. 3 The second-order spectra of $\mathrm{GO}$ and $\mathrm{rGO}$ samples: a GO with $\mathrm{Fe} / \mathrm{Al}_{2} \mathrm{O}_{3}$ catalyst, b rGO- $\mathrm{Fe} / \mathrm{Al}_{2} \mathrm{O}_{3}$, c GO- Fe/Mo/MgO, d rGO- Fe/Mo/ $\mathrm{MgO}$, e GO- $\mathrm{Ni} / \mathrm{Al}_{2} \mathrm{O}_{3}$, f rGO- $\mathrm{Ni} / \mathrm{Al}_{2} \mathrm{O}_{3}$

\section{SEM and TEM analysis}

Scanning and transmission electron microscopes were used to study the morphology and homogeneity of the samples. The SEM and TEM images were used to identify carbonaceous structures of the investigated materials. Different carbon nanostructures are presented in Fig. 4: carbon fishbone structure is formed when $\mathrm{Ni} / \mathrm{Al}_{2} \mathrm{O}_{3}$ and $\mathrm{Ni} / \mathrm{Cu} / \mathrm{Al}_{2} \mathrm{O}_{3}$ were used as catalysts and the nanotube structure received when applying $\mathrm{Fe} / \mathrm{Al}_{2} \mathrm{O}_{3}$ as catalyst during $\mathrm{CDM}$ (Fig. 4a) GO- with $\mathrm{Fe} / \mathrm{Al}_{2} \mathrm{O}_{3}$ catalyst, (e) GO- $\mathrm{Fe} / \mathrm{Al}_{2} \mathrm{O}_{3}$, (i) rGO$\mathrm{Fe} / \mathrm{Al}_{2} \mathrm{O}_{3}$, (b) GO- Fe/Mo/MgO, (f) $\mathrm{rGO}-\mathrm{Fe} / \mathrm{Mo} / \mathrm{MgO}$, (j) rGO- $\mathrm{Fe} / \mathrm{Mo} / \mathrm{MgO}, \mathrm{c}$ ) GO- $\mathrm{Ni} / \mathrm{Al}_{2} \mathrm{O}_{3}$, (g) rGO- Ni/Al ${ }_{2} \mathrm{O}_{3}$, (k) rGO- $\mathrm{Ni} / \mathrm{Al}_{2} \mathrm{O}_{3}$, (d) GO- Ni/Cu/ $/ \mathrm{Al}_{2} \mathrm{O}_{3}$, (h) GO- Ni/Cu/ $\mathrm{Al}_{2} \mathrm{O}_{3}$, (l) GO- Ni/Cu/Al $/ \mathrm{O}_{3}$ ). The SEM and TEM images present a wrinkled layered texture, which is associated with the presence of ultrathin $\mathrm{GO}$ and $\mathrm{rGO}$ sheets. Layers of reduced graphene oxide can be seen in the presented images, especially in the samples where $\mathrm{Fe} / \mathrm{Al}_{2} \mathrm{O}_{3}$ and $\mathrm{Ni} / \mathrm{Al}_{2} \mathrm{O}_{3}$ catalysts were used for the carbon nanofiber production. On the other hand, the images of a few samples show places with large agglomeration of nanocarbons (Fig. $4 \mathrm{~d}, \mathrm{~h}, \mathrm{l}-\mathrm{Ni} / \mathrm{Cu} /$ $\mathrm{Al}_{2} \mathrm{O}_{3}-\mathrm{GO}$ ), which affected the smaller efficiency of synthesis. The results confirm inhomogeneity of some samples.

SEM and TEM analyses were also used for investigation of the potential influence of heat treatment (pyrolysis at 700, $1500{ }^{\circ} \mathrm{C}$ and $2800^{\circ}$ ) on the structure of graphene oxide and reduced graphene oxide (Fig. 5.). The images of the synthesised samples with various heating treatment revealed that the $\mathrm{GO}$ and rGO material at $700{ }^{\circ} \mathrm{C}$ consists of randomly crumpled, aggregated, thin sheets (Fig. 5a-c). The higher temperatures of the $\mathrm{CDM}$ process influences more $\mathrm{GO}$ and $\mathrm{rGO}$ layers. 

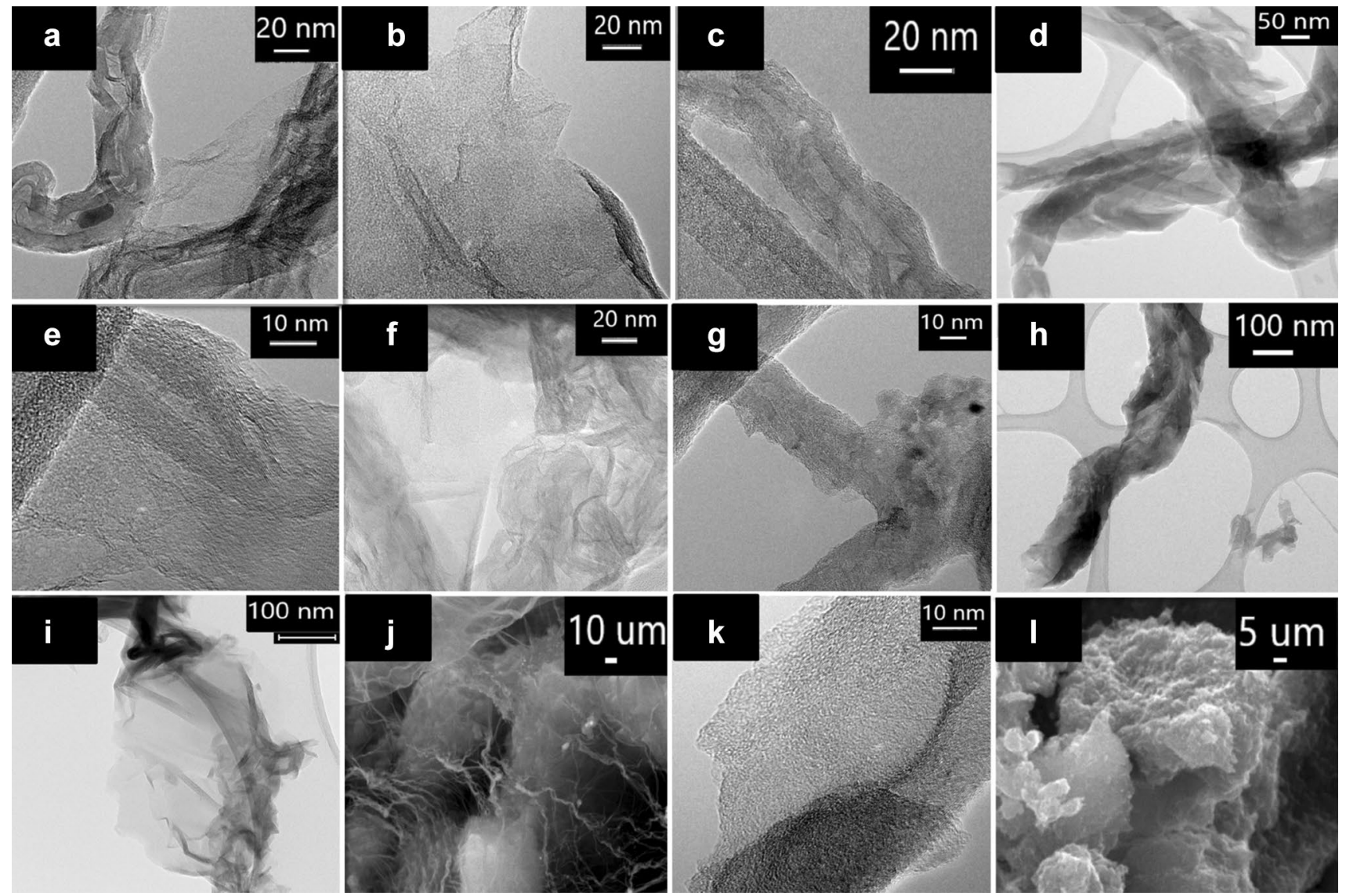

Fig. 4 TEM and SEM micrographs of rGO and GO synthesised from carbon nanofibers with various catalysts: a GO- with $\mathrm{Fe} / \mathrm{Al}_{2} \mathrm{O}_{3}$ catalyst, b GO- Fe/Mo/MgO, c GO- $\mathrm{Ni} / \mathrm{Al}_{2} \mathrm{O}_{3}$, d GO- Ni/Cu/ $/ \mathrm{Al}_{2} \mathrm{O}_{3}$,

e GO- $\mathrm{Fe} / \mathrm{Al}_{2} \mathrm{O}_{3}$, f rGO- $\mathrm{Fe} / \mathrm{Mo} / \mathrm{MgO}, \mathbf{g}$ rGO- $\mathrm{Ni} / \mathrm{Al}_{2} \mathrm{O}_{3}$, h GO- Ni/ $\mathrm{Cu} / \mathrm{Al}_{2} \mathrm{O}_{3}$, i rGO- $\mathrm{Fe} / \mathrm{Al}_{2} \mathrm{O}_{3}$, j rGO- $\mathrm{Fe} / \mathrm{Mo} / \mathrm{MgO}$, k rGO- $\mathrm{Ni} / \mathrm{Al}_{2} \mathrm{O}_{3}, \mathbf{l}$ GO- $\mathrm{Ni} / \mathrm{Cu} / \mathrm{Al}_{2} \mathrm{O}_{3}$

The nanotubes were better opened, thus there were more individual sheets. Less agglomeration of nanofibers in the samples with a higher temperature of the CDM process causes better exfoliation and efficiency of synthesis of graphene-like structures. In the comparison of graphitization effects, it is observed that the sample synthesised using a higher temperature in the CDM process had better efficiency and the layers of graphene were better formed.

The results of experiments show that the material from methane and biogas decomposition could be used with success in reduced graphene oxide synthesis. It needs to improve the efficiency of the process and also homogeneity of the samples. In future work, there is a possibility to check the influence of other catalysts and heat treatment, also the various compositions of gasses used in the degradation process. Results obtained in the present investigations will be helpful in future experiments.

\section{Conclusions}

Preliminary results indicate that different nanofilaments of carbon such as a fishbone, tubes etc. as a waste product of the catalytic methane or biogas decomposition process can be a good starting material for producing reduced graphene oxide sheets. These results should be improved in future experiments, especially efficiency and sample homogeneity. Analyzing the potential influence of heat treatment on the structure of graphene oxide and reduced graphene oxide, it was confirmed that the highest temperature of treatment on carbon nanotubes improves the area and surface of thin layers of nanofilaments. The aim of this work was to improve waste products from the CDM and biogas process. The research was an attempt to valorise the carbon nanofibers. CNF were obtained in a different process and in the presence of different catalysts. 

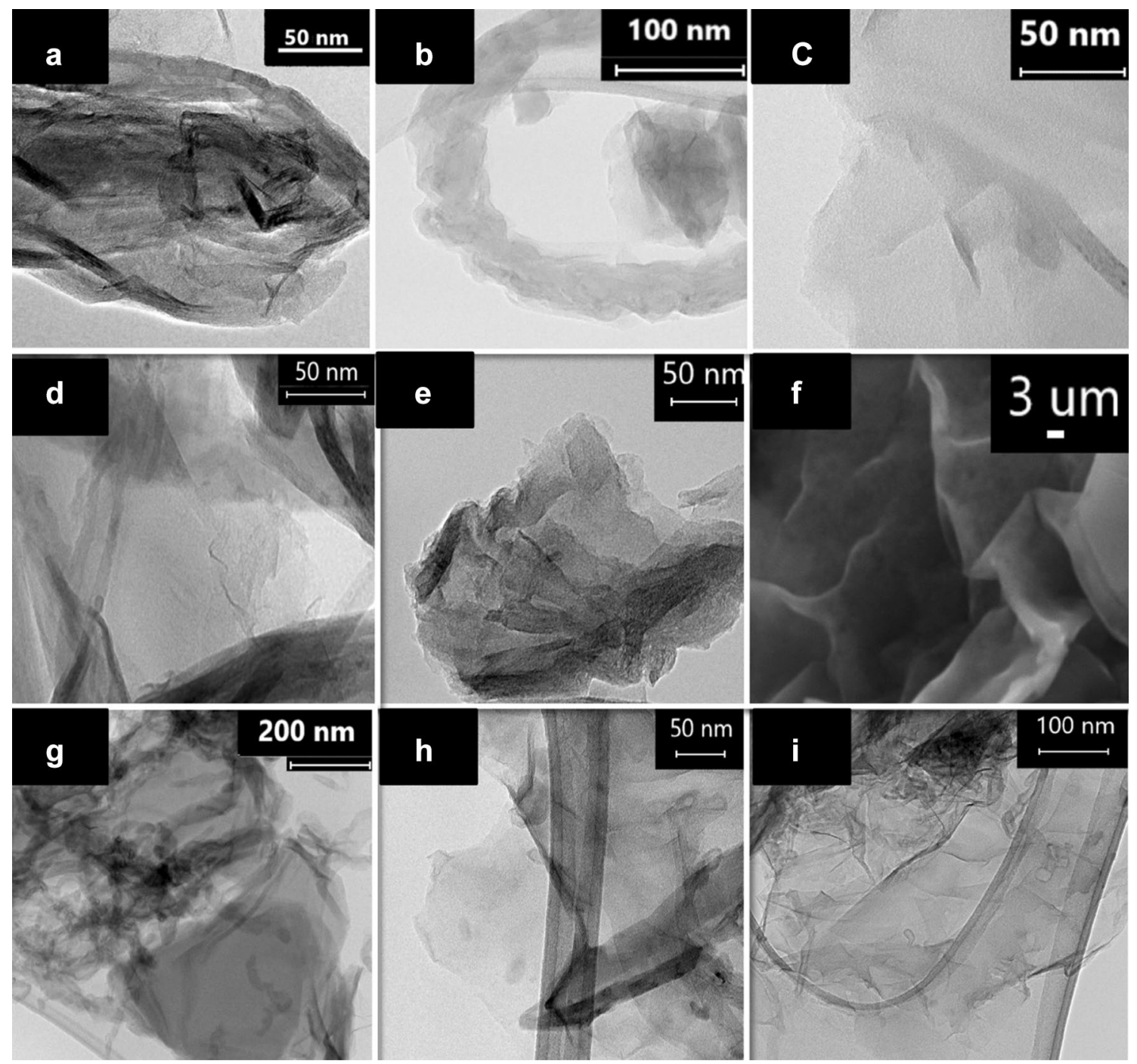

Fig. 5 TEM and SEM micrographs of rGO and GO synthesised from carbon nanofibers which were treated in different temperatures: a GO in $700{ }^{\circ} \mathrm{C}$, b rGO in $700{ }^{\circ} \mathrm{C}$, c rGO in $700{ }^{\circ} \mathrm{C}$, d GO in $1500{ }^{\circ} \mathrm{C}$,

Acknowledgements The authors acknowledge the financial support for traineeships from the project "Development of interdisciplinary doctoral studies at the Gdansk University of Technology in the field of modern technologies" (Project: POKL.04.01.01-00-368/09) cofinanced by the European Union under the European Social Fund.). K.J. also thanks Isabel Suelves and Rafael Moliner (Institute of Carbon in Zaragoza, Spain) for their help in the experimental work and fruitful discussions during the traineeship.

Open Access This article is distributed under the terms of the Creative Commons Attribution 4.0 International License (http://creativeco mmons.org/licenses/by/4.0/), which permits unrestricted use, distribution, and reproduction in any medium, provided you give appropriate credit to the original author(s) and the source, provide a link to the Creative Commons license, and indicate if changes were made. e rGO in $1500{ }^{\circ} \mathrm{C}$, f rGO in $1500{ }^{\circ} \mathrm{C}, \mathbf{g}$ GO in $2800{ }^{\circ} \mathrm{C}, \mathbf{h}$ rGO in $2800{ }^{\circ} \mathrm{C}$, i rGO in $2800{ }^{\circ} \mathrm{C}$

\section{References}

Abbas HF, Wan Daud WMA (2010) Hydrogen production by methane decomposition: a review. Int J Hydrogen Energy 35:1160-1190

Ayabe S, Omoto H, Utaka T, Kikuchi R, Sasaki K, Teraoka Y, Eguchi K (2003) Catalytic autothermal reforming of methane and propane over supported metal catalysts. Appl Catal A Gen 241:261-269. https://doi.org/10.1016/S0926-860X(02)00471-4

Bayat N, Rezaei M, Meshkani F (2016) Methane decomposition over $\mathrm{Ni}-\mathrm{Fe} / \mathrm{Al}_{2} \mathrm{O}_{3}$ catalysts for production of $\mathrm{CO}_{\mathrm{x}}$-free hydrogen and carbon nanofiber. Int J Hydrogen Energy 41:1574-1584. https ://doi.org/10.1016/j.ijhydene.2015.10.053

Benard P, Chahine R (2007) Storage of hydrogen by physisorption on carbon and nanostructured materials. Script Mater 56:803-808. https://doi.org/10.1016/j.scriptamat.2007.01.008

Bjorn Gaudernack SL (1998) Hydrogen from natural gas without release of $\mathrm{CO}_{2}$ to the atmosphere. Int J Hydrogen Energy 23:1087-1093 
Cao D, Li H, Wang Z, Wei J, Wang J, Liu Q (2015) Synthesis, nanostructure and magnetic properties of FeCo-reduced graphene oxide composite films by one-step electrodeposition. Thin Solid Films 597:1-6. https://doi.org/10.1016/j.tsf.2015.11.022

Chambers A, Park C, Baker RTK, Rodriguez NM (1998) Hydrogen storage in graphite nanofibers. J Phys Chem B 102:4253-4256

Cuesta A, Dhamelincourt P, Laureyns J, Martínez-Alonso A, Tascon JMD (1994) Raman microprobe studies on carbon materials. Carbon 32:1523-1532. https://doi.org/10.1016/0008-6223(94)90148 $-1$

Dettlaff A, Sawczuk M, Klugmann-Radziemska E, Czylkowski D, Miotk R, Wilamowska-Zawłocka M (2017) High-performance method of carbon nanotubes modification by microwave plasma for thin composite films preparation. RSC Adv 7:31940-31949. https://doi.org/10.1039/c7cA04707j

Dillon AC, Johns KM, Bekkedahl TA, Klang CH, Bethune DS, Heben MJ (1997) Storage of hydrogen in single-walled carbon nanotubes. Nature 386:377-379. https://doi.org/10.1038/386377a0

Ermakova MA, Ermakov DY, Chuvilin AL, Kuvshinov GG (2001) Decomposition of methane over iron catalysts at the range of moderate temperatures: the influence of structure of the catalytic systems and the reaction conditions on the yield of carbon and morphology of carbon filaments. J Catal 201:183-197. https:// doi.org/10.1006/jcat.2001.3243

Fan W, Wang Y, Chen J, Yuan Y, Li A, Wang Q, Wang C (2015) Controllable growth of uniform carbon nanotubes/carbon nanofibers on the surface of carbon fibers. RSC Adv 5:75735-75745. https ://doi.org/10.1039/c5ra15556h

Ferrari AC, Robertson J (2000) Interpretation of Raman spectra of disordered and amorphous carbon. Phys Rev B Condens 61:14095-14107

Ferrari AC, Meyer JC, Scardaci V, Casiraghi C, Lazzeri M, Mauri F, Piscanec S, Jiang D, Novoselov KS, Roth S, Geim AK (2006) Raman spectrum of graphene and graphene layers. Phys Rev Lett 97:1-4. https://doi.org/10.1103/PhysRevLett.97.187401

Goodman DW, Company C, Centre BT (2006) Methane decomposition: production of hydrogen and carbon filaments. Catalysis 19:164-183

Horváth A, Stefler G, Geszti O, Kienneman A, Pietraszek A, Guczi $\mathrm{L}$ (2011) Methane dry reforming with $\mathrm{CO}_{2}$ on CeZr-oxide supported $\mathrm{Ni}, \mathrm{NiRh}$ and $\mathrm{NiCo}$ catalysts prepared by sol-gel technique: relationship between activity and coke formation. Catal Today 169:102-111. https://doi.org/10.1016/j.cattod.2010.08.004

Hummers WS, Offeman RE (1958) Preparation of graphitic oxide. J Am Chem Soc 80:1339

Iijima S (1991) Helical microtubules of graphitic carbon. Nature 354:56-58. https://doi.org/10.1038/354056a0

Journet C, Bernier P (1998) Production of carbon nanotubes. Appl Phys A Mater Sci Process 67:1-9. https://doi.org/10.1007/s0033 90050731

Kim YA, Hayashi T, Endo M, Kaburagi Y, Tsukada T, Shan J, Osato K, Tsuruoka S (2005) Synthesis and structural characterization of thin multi-walled carbon nanotubes with a partially facetted cross section by a floating reactant method. Carbon 43:2243-2250. https ://doi.org/10.1016/j.carbon.2005.03.039

Kim H, Abdala AA, MacOsko CW (2010) Graphene/polymer nanocomposites. Macromolecules 43:6515-6530. https://doi. org/10.1021/ma100572e
Lázaro MJ, Ascaso S, Pérez-Rodríguez S, Calderón JC, Gálvez ME, Nieto MJ, Moliner R, Boyano A, Sebastián D, Alegre C, Calvillo L, Celorrio V (2015) Carbon-based catalysts: synthesis and applications. Comptes Rendus Chim 18:1229-1241. https://doi. org/10.1016/j.crci.2015.06.006

Martin CR (1994) Nanomaterials: a membrane-based synthetic approach. Science 266:1961-1966. https://doi.org/10.1126/scien ce.266.5193.1961

Martin-Gullon I, Vera J, Conesa JA, González JL, Merino C (2006) Differences between carbon nanofibers produced using $\mathrm{Fe}$ and $\mathrm{Ni}$ catalysts in a floating catalyst reactor. Carbon 44:1572-1580. https ://doi.org/10.1016/j.carbon.2005.12.027

Mirabile Gattia D, Antisari MV, Giorgi L, Marazzi R, Piscopiello E, Montone A, Bellitto S, Licoccia S, Traversa E (2009) Study of different nanostructured carbon supports for fuel cell catalysts. J Power Sources 194:243-251. https://doi.org/10.1016/j.jpows our.2009.04.058

Moliner R, Suelves I, Lázaro MJ, Echegoyen Y, Pinilla JL, Palacios JM (2006) Hydrogen production by thermo catalytic decomposition of natural gas: Ni-based catalysts. WHEC 1-9

Oberlin A, Endo M, Koyama T (1976) Filamentous growth of carbon through benzene decomposition. J Cryst Growth 32:335-349. https://doi.org/10.1016/0022-0248(76)90115-9

Pinilla JL, De Llobet S, Suelves I, Utrilla R, Lázaro MJ, Moliner R (2011) Catalytic decomposition of methane and methane $/ \mathrm{CO}_{2}$ mixtures to produce synthesis gas and nanostructured carbonaceous material. Fuel 90:2245-2253. https://doi.org/10.1016/j. fuel.2011.02.014

Pinilla JL, De Llobet S, Moliner R, Suelves I (2017) Ni-Co bimetallic catalysts for the simultaneous production of carbon nanofibres and syngas through biogas decomposition. Appl Catal B Environ 200:255-264. https://doi.org/10.1016/j.apcatb.2016.07.015

Ren J, Li F-F, Lau J, González-Urbina L, Licht S (2015) One-pot synthesis of carbon nanofibers from $\mathrm{CO}_{2}$. Nano Lett 15:6142-6148. https://doi.org/10.1021/acs.nanolett.5b02427

Rostrup-Nielsen J, Christensen TI, Dybkjaer I (1998) Steam reforming of liquid hydrocarbons. Stud Surf Sci Catal 113:81-95. https://doi. org/10.1016/S0167-2991(98)80277-2

Sadezky A, Muckenhuber H, Grothe H, Niessner R, Poschl U (2005) Raman microspectroscopy of soot and related carbonaceous materials: spectral analysis and structural information. Carbon 43:1731-1742. https://doi.org/10.1016/j.carbon.2005.02.018

Sebastián D, Suelves I, Lázaro MJ, Moliner R (2009) Carbon nanofibers as electrocatalyst support for fuel cells: effect of hydrogen on their properties in $\mathrm{CH}_{4}$ decomposition. J Power Sources 192:5156. https://doi.org/10.1016/j.jpowsour.2008.11.092

Zhang Y, Cho UR (2017) Enhanced thermo-physical properties of nitrile-butadiene rubber nanocomposites filled with simultaneously reduced and functionalized graphene oxide. Polym Compos. https://doi.org/10.1002/pc.24335

Zou G, Zhang D, Dong C, Li H, Xiong K, Fei L, Qian Y (2006) Carbon nanofibers: synthesis, characterization, and electrochemical properties. Carbon 44:828-832. https://doi.org/10.1016/j.carbo n.2005.10.035 